\title{
Selected physiological parameters of creeping willow [Salix repens subsp. arenaria (L.) Hiit.]: a shrubby plant inhabiting degraded industrial areas
}

\author{
Marta Śliwa ${ }^{1} \cdot$ Paweł Kaszycki ${ }^{1}$ Paulina Supel ${ }^{1}$ - Andrzej Kornaś ${ }^{2} \cdot$ Adriana Kaproń $^{3} \cdot$ Ulrich Lüttge $^{4}$. \\ Zbigniew Miszalski ${ }^{3,5}$
}

Received: 30 October 2018 / Accepted: 23 May 2019 / Published online: 20 June 2019

(c) The Author(s) 2019

\begin{abstract}
Key message Salix arenaria from sandy sites tended to grow fast, notwithstanding particular stress conditions in the desert habitat.

Abstract The study was aimed at characterizing main adaptive changes in Salix arenaria exposed to harsh conditions of a desert-like environment. It was clearly shown that the plant was capable of adapting most of its photosynthesis parameters to enable efficient vegetative performance. A closer look at plant anatomical structures made it possible to better define the changes developed by plants populating sandy habitats as compared with the vegetation sites located in the nearby forest. The desert environment generated physiological stress of water availability and increased the plants' water use efficiency (WUE) during photosynthesis. All the collected data indicate that the photochemical apparatus in S. arenaria inhabiting desert areas got slightly adapted to strong light and drought, which involved some photoinhibition mechanism and the reduction of the reaction center (RC) size (photosystem II, PSII), while keeping the plant photochemical activity at a similar level. Determination of microbial frequency in the sandy soil of the desert-growing plants showed microbiota population high enough as not to hamper plant growth. The root zones of both the desert-growing and control plants provided favorable conditions enabling populous microbial proliferation, particularly biostimulated during the spring season. The arbuscular mycorrhiza was also shown to be well developed and independent of the original plant habitat (desert or forest).
\end{abstract}

Keywords Plant anatomy $\cdot$ Chlorophyll $a$ fluorescence $\cdot{ }^{13} \mathrm{C}$ discrimination $\cdot$ Microbiota $\cdot$ Mycorrhiza $\cdot$ Błędowska Desert

Communicated by P. Courty.

Ulrich Lüttge

luettge@bio.tu-darmstadt.de

$\triangle$ Zbigniew Miszalski

miszalski@ifr-pan.edu.pl

1 Unit of Biochemistry, Institute of Plant Biology and Biotechnology, Faculty of Biotechnology and Horticulture, University of Agriculture in Kraków, al. 29 Listopada 54, 31-425 Kraków, Poland

2 Institute of Biology, Pedagogical University, ul. Podchorążych 2, 30-084 Kraków, Poland

3 The Franciszek Górski Institute of Plant Physiology of the Polish Academy of Sciences, ul. Niezapominajek 21, 30-239 Kraków, Poland

4 Department of Biology, Darmstadt University of Technology, Schnittspahnstrasse 3-5, 64287 Darmstadt, Germany

5 Malopolska Center of Biotechnology, Jagiellonian University, ul. Gronostajowa 7A, 30-387 Kraków, Poland

\begin{tabular}{|c|c|}
\hline \multicolumn{2}{|c|}{ Abbreviations } \\
\hline ar & Arbuscule \\
\hline Chl $a$ & Chlorophyll $a$ \\
\hline $\mathrm{DI}_{0} / \mathrm{RC}$ & $\begin{array}{l}\text { Total energy dissipation not trapped by the } \\
\text { PSII reaction center }\end{array}$ \\
\hline $\mathrm{ET}_{0} / \mathrm{RC}$ & $\begin{array}{l}\text { Rate of electron transfer by the active PSII } \\
\text { reaction center }\end{array}$ \\
\hline hy & Hyphae \\
\hline $\mathrm{CFU}$ & Colony-forming unit \\
\hline PEPC & Phosphoenolpyruvate carboxylase \\
\hline PPFD & $\begin{array}{l}\text { Photosynthetic photon flux density (irradi- } \\
\text { ance), } \mu \mathrm{mol} \mathrm{m} \mathrm{m}^{-2} \mathrm{~s}^{-1}\end{array}$ \\
\hline PSII & Photosystem II \\
\hline $\mathrm{RC}$ & Reaction center \\
\hline RuBisCO & $\begin{array}{l}\text { Ribulose-bis-phosphate carboxylase/ } \\
\text { oxygenase }\end{array}$ \\
\hline $\mathrm{TR}_{0} / \mathrm{RC}$ & Energy trapping of one active reaction cent \\
\hline$\delta^{13} \mathrm{C}$ & Carbon ${ }^{13} \mathrm{C}:{ }^{12} \mathrm{C}$ isotope ratio \\
\hline WUE & Water use efficiency \\
\hline
\end{tabular}

\section{Abbreviations}

ar $\mathrm{DI}_{0} / \mathrm{RC}$ Total energy dissipation not trapped by the PSII reaction center reaction center

hy Hyphae

CFU Colony-forming unit

PEPC Phosphoenolpyruvate carboxylase ance), $\mu \mathrm{mol} \mathrm{m} \mathrm{m}^{-2} \mathrm{~s}^{-1}$

PSII Photosystem II

RC Reaction center

RuBisCO Ribulose-bis-phosphate carboxylase/ oxygenase

$\delta^{13} \mathrm{C}$ Water use efficiency 


\section{Introduction}

The Błędowska Desert ("Pustynia Błędowska") is a complex of two sand habitats that is inland dunes and stenothermic grasslands, covering a total area of approximately $33 \mathrm{~km}^{2}$. It has been classified under the European frame program dedicated to networks of landscape protection areas NATURA 2000-Area Code PLH-120014 (Ordinance of the Regional Director for Environmental Protection, Kraków, Katowice, 2014). The desert is located in the North-West part of the so-called Jura Krakowsko-Częstochowska (Polish Jurassic Highland or Cracow-Częstochowa Jura Chain), on the borders of the Śląska (Silesian) and Olkuska Highlands $\left(50^{\circ} 21^{\prime} 23.4^{\prime \prime} \mathrm{N}\right.$ $19^{\circ} 30^{\prime} 56.3^{\prime \prime}$ ) (Szostak et al. 2016). Among the causes of the mentioned area desertification were: extensive deforestation resulting from extractive industry expansion (especially mining) starting from the 12th century, animal grazing, and eolic processes (wind-promoted erosion) (Pełka-Gościniak et al. 2014). Until mid-20th century, the described area was almost totally deprived of ligneous and woody vegetation. In addition, the desert-like landscape character was further promoted by wide utilization of surrounding zinc and lead deposits (still ongoing, although limited to the region of Olkusz located nearby) (Report on the environmental impact, 2007), drainage of underground water due to the mining activities and for using the area as a military training ground (Szostak et al. 2016).

Currently, the Błędowska Desert undergoes both spontaneous, natural secondary succession, and anthropogenic land afforestation and shrub introduction. To fix the loose, windblown and volatile sands, some chosen herbaceous, as well as shrubby plants were introduced. Among the most important species are sand ryegrass (also known as sea lymegrass or beach wildrye, Leymus arenarius (L.) Hochst. (syn. Elymus arenarius L.), sharp-leaf willow (Salix acutifolia Willd.) and creeping willow (Salix repens subsp. arenaria (L.) Hiit.) (Rahmonov and Oleś 2010).

It is frequently observed and obviously a general ecological feature that extended sand plains get covered by isolated vegetation islands. This is seen in coastal alluvial sand plains in Venezuela (Medina et al. 1989) as well as in the coastal sand dunes of the restingas in Brazil (Dias and Scarano 2007; Lüttge 2007). It is fascinating that the sand plain of the Błędowska Desert presents a landscape physiognomy similar to these tropical habitats (Fig. 1a). The reason for this general feature may be that the vegetation islands are started by individual pioneer plants which function as nurse plants (Dias and Scarano 2007; Lüttge et al. 2012) supporting the establishment of other species as well as soil microbiota. Although developing vegetation islands may also be dying off again, in successions, denser vegetation can develop from them (Medina et al. 1989).
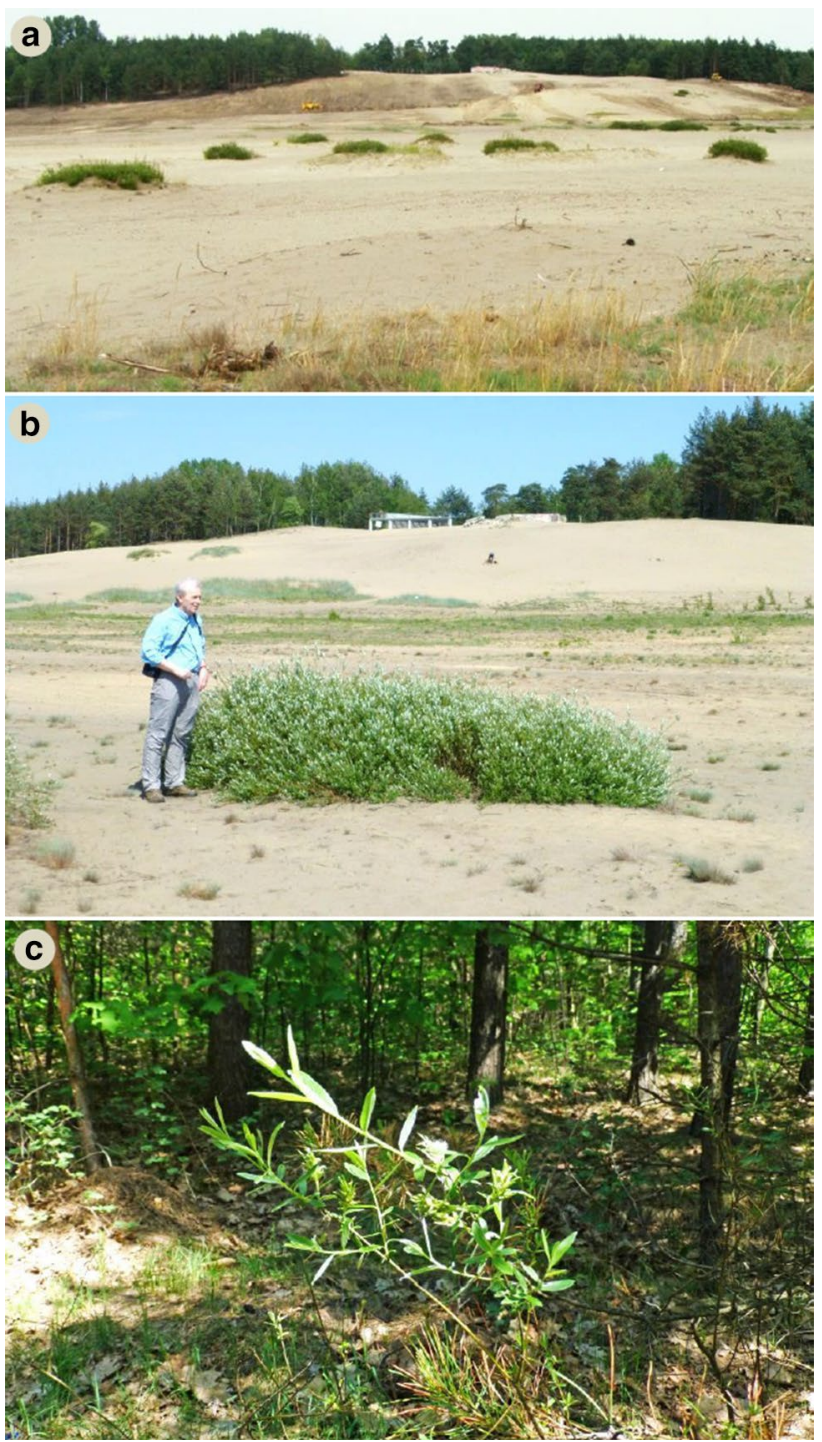

Fig. 1 Survey of the Błędowska Desert "Pustynia Błędowska" with vegetation islands on the sand plain (a), individual vegetation island of a creeping willow (Salix repens subsp. arenaria (L.) Hiit.) and surrounding forest above (b), and $S$. arenaria in the surrounding forest (c)

A typical nurse plant in the restingas is Clusia hilariana Schltdl. (Dias and Scarano 2007; Lüttge et al. 2012). In the Błędowska Desert, quite obviously $S$. arenaria plays such a role (Fig. 1a, b). S. arenaria is a subspecies of a desertintroduced shrub of the Salicaceae family, belonging to the species Salix repens. It has also been reported to enter desert wastelands following natural succession processes (Rahmonov et al. 2009). According to the Grime model, it uses a type of a ruderal strategy which allows for fast population of open environments suffering from ecosystem disorders, e.g., resulting in the tree stand structure disruption (Wonkka et al. 2013). The plant has evolved adaptation capacities to vegetation at open spaces, predominately due to generation 
of long, flexible branches and leather-like, double-sided hairing of leaves (wax coating forms an indumentum). This species inhabits Asia and Europe, and in Poland, it occurs naturally on the Baltic coast. The plant is known to be resistant to physiological stress resulting from drought and frost (Zander and Graf 2010). It can grow on peat and sandy soils; moreover, when it appears at sites characterized by dry sands and/or poor soils, it helps to create settlement conditions for herbaceous and grass plants, and promotes colonization with soil microorganisms.

The proper development and growth of many plant species is supported by proliferation of diverse soil microbiota, especially within the root zones. Close interaction between rhizospheral bacteria with the plant has a strong mutual effect involving both morphological changes and biochemical adjustments (Facelli et al. 2009). For the case of plant associations with soil-borne fungi, mycorrhiza is a widespread form of symbiosis between roots and fungal cells (Bonfante and Genre 2010; Smith and Read 2008). The fungus is able to deeply penetrate the soil substrate and can take up considerable amounts of water, mineral constituents $(\mathrm{N}, \mathrm{P}, \mathrm{K})$, and other micronutrients like $\mathrm{Zn}, \mathrm{Cu}, \mathrm{Ni}, \mathrm{S}, \mathrm{Mn}$, $\mathrm{B}, \mathrm{Fe}, \mathrm{Ca}$, and $\mathrm{Mg}$ (Allen et al. 2003). Thus, it enables the host plant to have improved access to a variety of essential nutrients. In turn, the mycorrhizal fungi obtain plant carbohydrates which promote their growth (Smith et al. 2010). The most important function of mycorrhizal fungi is their involvement in soil substrate aggregation and stabilization (Rillig and Mummey 2006). In consequence, their presence and activity prevents erosion and enhances the agronomic soil value as well as improves environmental conditions favoring development of other organisms (Díaz-Zorita et al. 2002). In addition, mycorrhizal fungi act as protective agents against pathogens, stimulating production of plant-beneficial exudates, and often synthesize hormones biostimulating growth of the host (Rillig and Mummey 2006). For the case of arbuscular mycorrhiza formed by numerous representatives of the Glomeromycota division (Dickson et al. 2007; Smith and Read 2008; Smith et al. 2010), the fungus is localized within the host root, where it penetrates into the root primary cortex. Then, inside the root cells, it generates specific branched hyphae called arbusculae.

Mycorrhizal frequency determination is a convenient technique enabling to monitor changes associated with natural succession processes occurring in woodlands surrounding desert-like areas as well as with afforestation actions (Orłowska et al. 2002). An alternative and complementary approach is to analyze photosynthesis course and physiological parameters of the plants populating sandy sites. The effect of unfavorable conditions is usually well reflected by photosystem II (PS II) efficiency (Baker 2008). A decreased PS II yield typically results from the elevated energy amount dissipated as heat. This, in turn, leads to increased values of the following parameters: the amount of energy absorbed (trapped energy flux per PSII reaction center, $\mathrm{TR}_{0} / \mathrm{RC}$ ), rate of electron transport (electron transport flux per reaction center, $\mathrm{ET}_{0} / \mathrm{RC}$ ), and excess energy dissipation in the form of heat and fluorescence (dissipated energy flux per reaction center, $\mathrm{DI}_{0} / \mathrm{RC}$ ) (Kalaji et al. 2011).

Some insights into biomass building and water relations can be provided by analyses of ${ }^{13} \mathrm{C} /{ }^{12} \mathrm{C}$ carbon isotope discrimination during photosynthesis (Cernusak et al. 2013; Farquhar et al. 1989a; Park and Epstein 1961). S. arenaria is an obligate $\mathrm{C}_{3}$ plant with primary photosynthetic $\mathrm{CO}_{2}$ fixation via RubisCO (ribulose-bis-phosphate carboxylase/ oxygenase) with a ${ }^{13} \mathrm{C}$ discrimination of $\mathrm{CO}_{2}$ of $27 \%$ at the enzyme level (Beerling and Woodward 1993). However, during the overall photosynthetic process, this is overlaid by carbon isotope discrimination of $\mathrm{CO}_{2}$ diffusion particularly via the stomata. When stomatal conductance is high, the discrimination of $\mathrm{CO}_{2}$ with the heavier isotope ${ }^{13} \mathrm{C}$ is lower (less negative $\delta^{13} \mathrm{C}$ values) than for the case when diffusion via the stomata is restricted. Stomatal conductance is inversely related to water use efficiency (WUE). Thus, plants suffering from water deficit usually use water more efficiently when calculated for the amount of fixed $\mathrm{CO}_{2}$. Decreasing stomatal conductance results in lowering of the leaf intercellular $\mathrm{CO}_{2}$ level, which finally leads to an increased WUE (Seibt et al. 2008).

The aim of the study was to detect changes in morphology, anatomy, and in the course of photosynthesis, associated with $S$. arenaria growing under harsh desert environmental conditions with limited access to water resources and nutrients. Research on adaptational potential of plants inhabiting depleted ecosystems has recently become an important issue in the context of global climate change that leads to expected progressive degradation of large areas. In addition, a possible role of soil microorganisms was analyzed in terms of their involvement in S. arenaria adaptive processes. Microbiota observations were focused on determination of bacterial and fungal colonization rate within the root zone and on preliminary characterizing plant symbiosis with arbuscular fungi.

\section{Materials and methods}

\section{Plant material}

The study concerned the shrubby plant Salix repens subsp. arenaria (L.) Hiit. (a creeping willow), growing in the sandy area of the Błędowska Desert ("Pustynia Błędowska"). The plant has been populating several desert sites upon natural succession. Three healthy, individual plant objects were arbitrary selected from different localities and subjected to anatomical investigations. For chlorophyll fluorescence 
measurements, each plant was examined with at least 20-30 repetitions (as limited by the number of leaf clips) every time interval (see below). In the case of C-isotope measurements, the pooled leaf samples from particular plants were analyzed in duplicates. As control objects, the plants belonging to the same subspecies were selected at two localities in the pine tree forest surrounding the desert area. The analyses were made under favorable atmospheric conditions, during warm and sunny days (maximum temperature of approximately $25^{\circ} \mathrm{C}$ ), independently at spring and summer during 2017 and 2018 seasons.

\section{Anatomy of plants}

Cross-sectional hand-cut fragments of stems and leaves were observed in distilled water using a Nikon ECLIPSE Ni light and epifluorescence microscope (Nikon, Japan) equipped with Microscope Camera Digital Sight series DS-Filc and NIS Imaging software, Nikon version 4.11. The distribution of chlorophyll was determined based on autofluorescence of Chl $a$.

\section{Discrimination of a carbon isotope ${ }^{13} \mathrm{C}$}

Prior to analyses of carbon isotope content, freeze-dried leaf material was homogenized in an agate mortar until a finegrained powder was obtained. Determination of the carbon isotope ratio, $\delta^{13} \mathrm{C}$, was performed with the continuous flow technique using a Finnigan MAT 253 mass spectrometer coupled with a Flash HT Elemental Analyzer. The samples were weighed and then burned off in a furnace at $1020^{\circ} \mathrm{C}$. Small volume aliquots of oxygen were added to the system to provide complete burning of the organic matter and transforming it into gases. The resultant $\mathrm{CO}_{2}$ was then fractionated using chromatographic columns heated to $45^{\circ} \mathrm{C}$. Next, it was transported within the helium stream through the ConFlo IV Interface to the mass spectrometer to enable determination of the ratio of particular carbon isotope contents. The calculations were made employing internal standards USGS 40, USGS 41, and IAEA 600 (Coplen et al. 2006). The carbon isotope ratio is expressed as:

$\delta^{13} \mathrm{C}=\left(\frac{\left({ }^{13} \mathrm{C} /{ }^{12} \mathrm{C}\right)_{\text {sample }}}{\left({ }^{13} \mathrm{C} /{ }^{12} \mathrm{C}\right)_{\text {standard }}}-1\right) \cdot 1000 \%$.

\section{Chlorophyll fluorescence measurements}

The analyses were performed using Dual-PAM-100 (P700 \& Chlorophyll Fluorescence Measuring System, Walz Messund Regeltechnik, Germany) according to the manual.

\section{Determination of chlorophyll $a$ fluorescence kinetics}

Photochemical parameter analyses were carried out using a Handy PEA spectrofluorimeter (Hansatech Instruments, UK). The leaves were dark-adapted for $20 \mathrm{~min}$ by clipping with leaf clips. Chlorophyll $a(\mathrm{Chl} a)$ fluorescence was excited at the wavelength $\lambda=620 \mathrm{~nm}$. The overall light intensity (irradiance, photosynthetic photon flux density, PPFD), was measured at particular experimental sites and at defined times of the day (see below) with the use of a Li-COR LI-189 luxometer (Lincoln, Nebraska, USA). Photochemical activity was determined based on the measurements of the following photochemical parameters (see the abbreviations list for parameter definitions): $\mathrm{TR}_{0} / \mathrm{RC}, \mathrm{ET}_{0} /$ $\mathrm{RC}, \mathrm{DI}_{0} / \mathrm{RC}$. All the parameters were measured at strictly defined hours $(7: 00,10: 30,14: 00,17: 30)$, so that their daily courses could be monitored.

\section{Bacteria and fungi colonizing the rhizosphere of Salix arenaria}

To determine microbial frequency within the root zone of the tested plants inhabiting the desert and forest areas, the root systems were carefully pulled out and the soil material shaken off and collected. The root system of $S$. arenaria creates a network of creeping shallow roots (penetrating less than $20 \mathrm{~cm}$ of soil layer) that spread in all directions and are easy accessible. In a sandy soil of both the desert and forest localities, it was, thus, relatively easy to obtain undamaged, fine roots for further analyses. Either bacterial or fungal cell population densities were monitored in aqueous soil extracts with a standard Koch surface-plating method, using Petri dishes that contained solidified media: $2.5 \%$ enriched agar (Biocorp, Poland) or a 6.5\% Sabouraud medium, respectively. Colony-forming units (CFUs) were macroscopically evaluated and counted after 3-4 day incubation at room temperature and the resultant cell frequencies were expressed as CFU per $\mathrm{g}$ d.w. of original soil samples (Kaszycki et al. 2014).

\section{Assessment of mycorrhizal fungi}

Staining of fungal structures occurring inside $S$. arenaria roots was carried out with the modified method of Phillips-Hayman (Phillips and Hayman 1970). The roots were digested at $90{ }^{\circ} \mathrm{C}$ in $10 \% \mathrm{KOH}(2 \mathrm{~h})$ and then, after washing, were bleached in $10 \% \mathrm{H}_{2} \mathrm{O}_{2}(1 \mathrm{~h})$ and acidified in $1 \% \mathrm{HCl}$ solution $(30 \mathrm{~min})$. Next, the root material was transferred to $0.05 \%$ solution of aniline blue in lactic acid (Van Der Heijden and Kuyper 2001). The staining procedure was performed at room temperature. Arbuscular mycorrhiza was assessed following the method of Trouvelot et al. (1986), applying the Mycocalc software (http://www2.dijon.inra. 
fr/mychintec/Mycocalc-prg/download.html). Microscopic observations were done under magnification of $40 \times$ using a Nikon ECLIPSE E200 optical microscope equipped with a Nikon D5100 digital camera.

\section{Statistical data analysis}

Collection of plant samples was carried out as described above (see "Materials and methods"). All the data are presented as mean values with a standard deviation (SD). Photochemical and carbon isotope discrimination results were analyzed using the statistical software Statistica 13.1 (StatSoft, 64 bit). One-way analysis of variance (ANOVA) was followed by the difference determination using a post hoc Scheffe's test at $p \leq 0.05$. Microbiological frequency was determined upon three repetitions. SD values, represented by respective error bars in Fig. 6, were calculated on the basis of multiple repetitive cell colony counts and were assumed as $25 \%$ of the original data.

\section{Results and discussion}

Morphological evaluation of $S$. arenaria indicates that the plants got adapted to growth at desert conditions by forming long and flexible, wind-resistant branches together with thick leaves coated with waxy surfaces providing protection against enhanced solar radiation. A closer look at plant anatomical structures (Figs. 1, 2, 3, 4) enabled to better define the main adaptive changes developed by plants populating sandy habitats as compared with the vegetation sites located in the nearby forest. Surfaces of the desert-collected leaves were covered with considerably higher number of trichomes (dead trichomes) that tended to form an indumentum, observed both on the upper and bottom sides. Figure 2 shows leaf cross sections, which prove that the vascular conductive tissue as well as the strengthening tissue (collenchyma and sclerenchyma) were better developed for willows grown in the desert, which was especially pronounced within the area of main leaf vascular tissues. Young (less than 1 year old) stems of the desert-inhabiting plants (a stem cross section is presented in Fig. 3) were covered with a thicker layer of cutin. For older (2 years old) stems (Fig. 4), the cutin layer was also thicker and the formation of the strengthening tissue was promoted. In general, it is apparent that the plants collected from sites at the Błędowska Desert tended to grow faster, notwithstanding particular stress conditions in the desert habitat. It was possibly a result of the enhanced exposure to sunlight during the early stages of development.

The carbon isotope ratios clearly indicate that the desert environment generated physiological stress of availability of water. For that reason, the plants of $S$. arenaria probably increased their WUE during photosynthesis, which is manifested by higher discrimination and a more negative $\delta^{13} \mathrm{C}$ value (Table 1 ). Interestingly, $\delta^{13} \mathrm{C}$ differed by $4.1 \%$ o in both habitats. Although several factors are expected to be involved in making this difference, in a comparison of plants with the same mode of $\mathrm{C}_{3}$-photosynthesis and the basic ${ }^{13} \mathrm{C}$-discrimination of RubisCO, it is appropriate to relate this difference predominantly to WUE (Ehleringer and Rundel 1989; Farquhar et al. 1989a, b; Guehl et al. 2004; Livingston et al. 1999; Scheidegger et al. 2000); still, an increased activity of PEPC, which is characterized by a lower ${ }^{13} \mathrm{C}$-discrimination, cannot be excluded for the case of stress-exposed plants (Farquhar et al. 1989a).

From the carbon isotope ratio, $\delta^{13} \mathrm{C},{ }^{13} \mathrm{C}$-discrimination, $\Delta$, is obtained as follows:

$\Delta=\frac{\delta_{\mathrm{a}}-\delta_{\mathrm{p}}}{1000+\delta_{\mathrm{p}}} \cdot 1000 \%$,

where $\delta_{\mathrm{a}}$ and $\delta_{\mathrm{p}}$ are the $\delta^{13} \mathrm{C}$ values in the atmosphere and in the plant material, respectively, and $\delta_{\mathrm{a}}$ is $-8 \%$. Correlations or proportionalities $(\approx)$ are as follows:

$\Delta \approx \frac{p_{\mathrm{CO}_{2}}^{\mathrm{i}}}{p_{\mathrm{CO}_{2}}^{\mathrm{a}}} \approx g_{\mathrm{H}_{2} \mathrm{O}} \approx \frac{1}{\mathrm{WUE}}$,

where $p_{\mathrm{CO}_{2}}^{\mathrm{i}}$ and $p_{\mathrm{CO}_{2}}^{\mathrm{a}}$ are the $\mathrm{CO}_{2}$ partial pressures in the atmosphere and in the leaf intercellular air, respectively; $g_{\mathrm{H}_{2} \mathrm{O}}$ is leaf hydraulic conductivity or stomatal conductance to water vapor, and WUE is water use efficiency (Farquhar et al. 1982), and

$\Delta=4.4+22.6 \cdot \frac{p_{\mathrm{CO}_{2}}^{i}}{p_{\mathrm{CO}_{2}}^{a}}$,

where $4.4 \%$ is ${ }^{13} \mathrm{C}$-discrimination due to $\mathrm{CO}_{2}$ diffusion in air and $22.6 \%$ is the difference between this and the net fractionation by RubisCO carboxylation itself (viz. 27\%o). With these relations, the carbon isotope analyses support the notion that, in the desert site, $S$. arenaria operates at a considerably higher WUE with the sacrifice of operating at a lower $p_{\mathrm{CO}_{2}}^{\mathrm{i}}$ than at the forest site (Table 1).

However, the plants populating the desert areas did not exhibit considerable malfunctions on the level of the photochemical apparatus. Some differences were, nevertheless, apparent when Chl $a$ fluorescence kinetic parameters of $S$. arenaria leaves were considered. The data are shown in Fig. 5. The most pronounced changes could be observed for determination of the electron transport velocity per PSII reaction center (the $\mathrm{ET}_{0} / \mathrm{RC}$ parameter, Fig. 5a) and energy capture by a single reaction center $\left(\mathrm{TR}_{0} / \mathrm{RC}, \mathrm{Fig} .5 \mathrm{~b}\right)$. In the desert-analyzed leaves, both $\mathrm{ET}_{0} / \mathrm{RC}$ and $\mathrm{TR}_{0} / \mathrm{RC}$ were lower than in the controls at every investigation time of the 

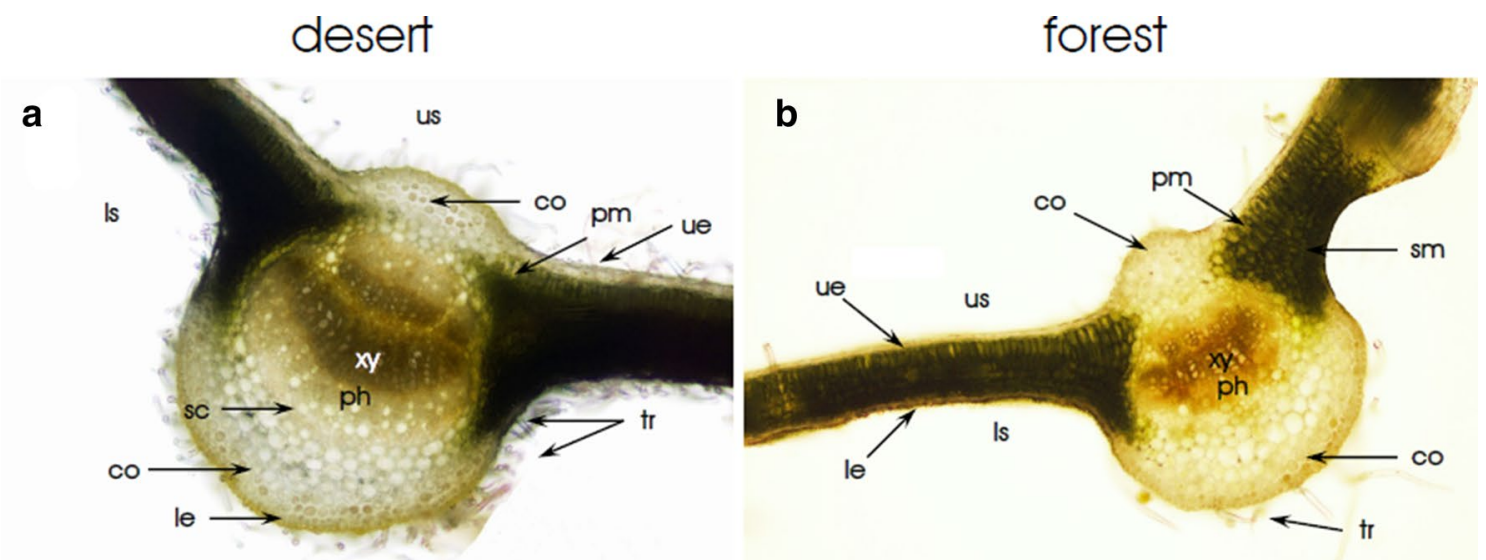

$100 \mathrm{um}$
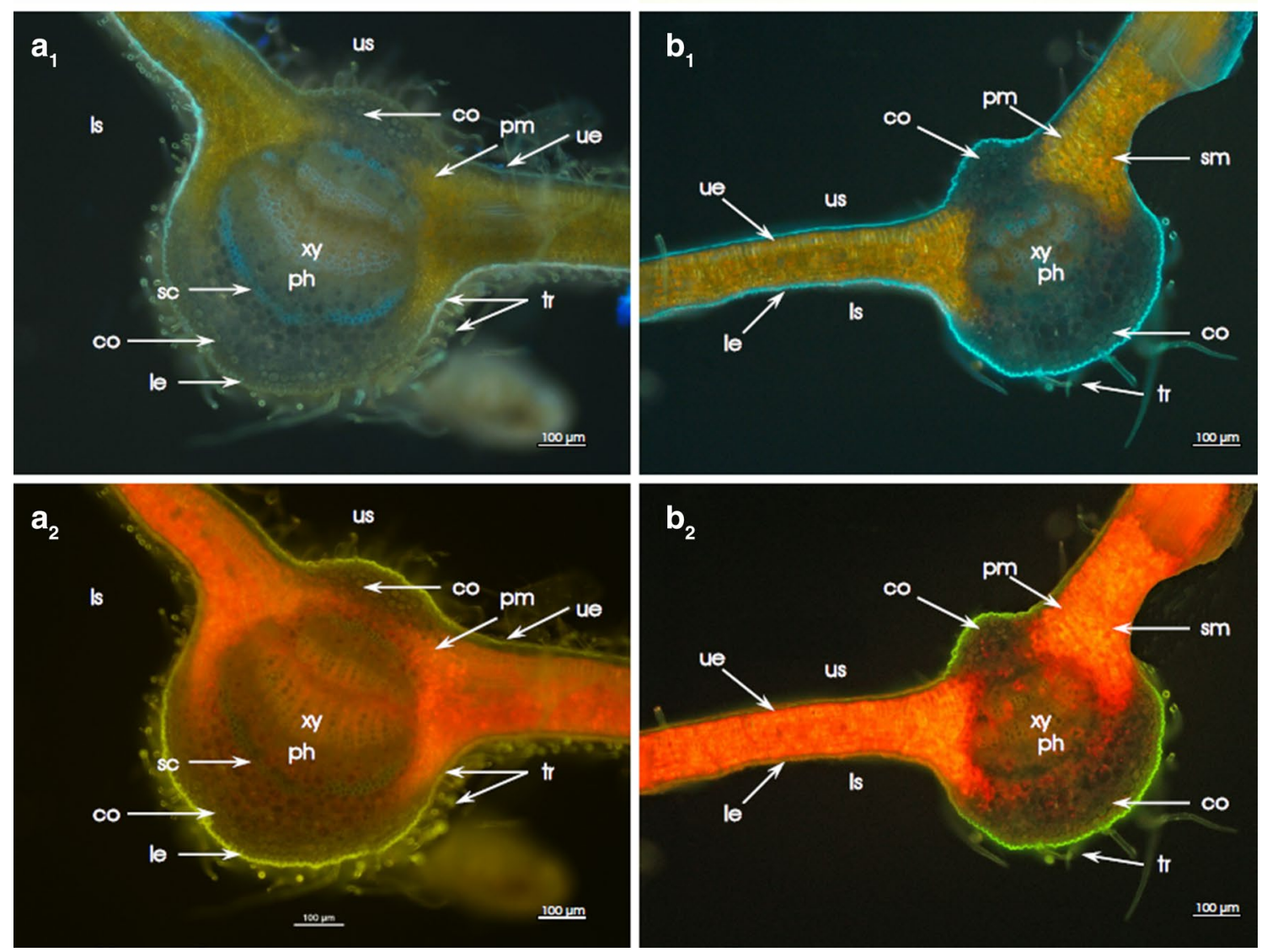

Fig. 2 Representative cross section of central part leaf of Salix repens subsp. arenaria (L.) Hiit. collected from Błędowska Desert "Pustynia Błędowska" (a) and surrounding forest (b) observed by light (a, b) and using epifluorescence microscopy $\left(\mathbf{a}_{1}, \mathbf{a}_{2}\right.$ and $\left.\mathbf{b}_{1}, \mathbf{b}_{2}\right)$. Red and blue colors correspond to autofluorescence of chlorophyll and cell

day, proving statistically significant changes at all measurement hours except for 10:30, and, taken together, indicating photoinhibition. Thus, these differences were rather stable during the day course and one could suggest that this phenomenon may have resulted from differences in structure of some components of the electron transport chain (PSI and walls, respectively. co-collenchyma; le-lower epidermis; ls—lower surface; ph—phloem; pm—palisade mesophyll cells; sc—sclerenchyma; sm-spongy parenchyma cells; tr-trichome; ue-upper epidermis; us—upper surface; $x y-x y l e m$

PSII). The above findings support the idea that the tested desert-growing plants undergo physiological stress associated with drought and excessive exposure to sunlight. At the same time, the parameter $\mathrm{DI}_{0} / \mathrm{RC}$, representing total dissipation (heat or fluorescence) of the energy not captured by single reaction center, was not significantly changed (Fig. 5c), 

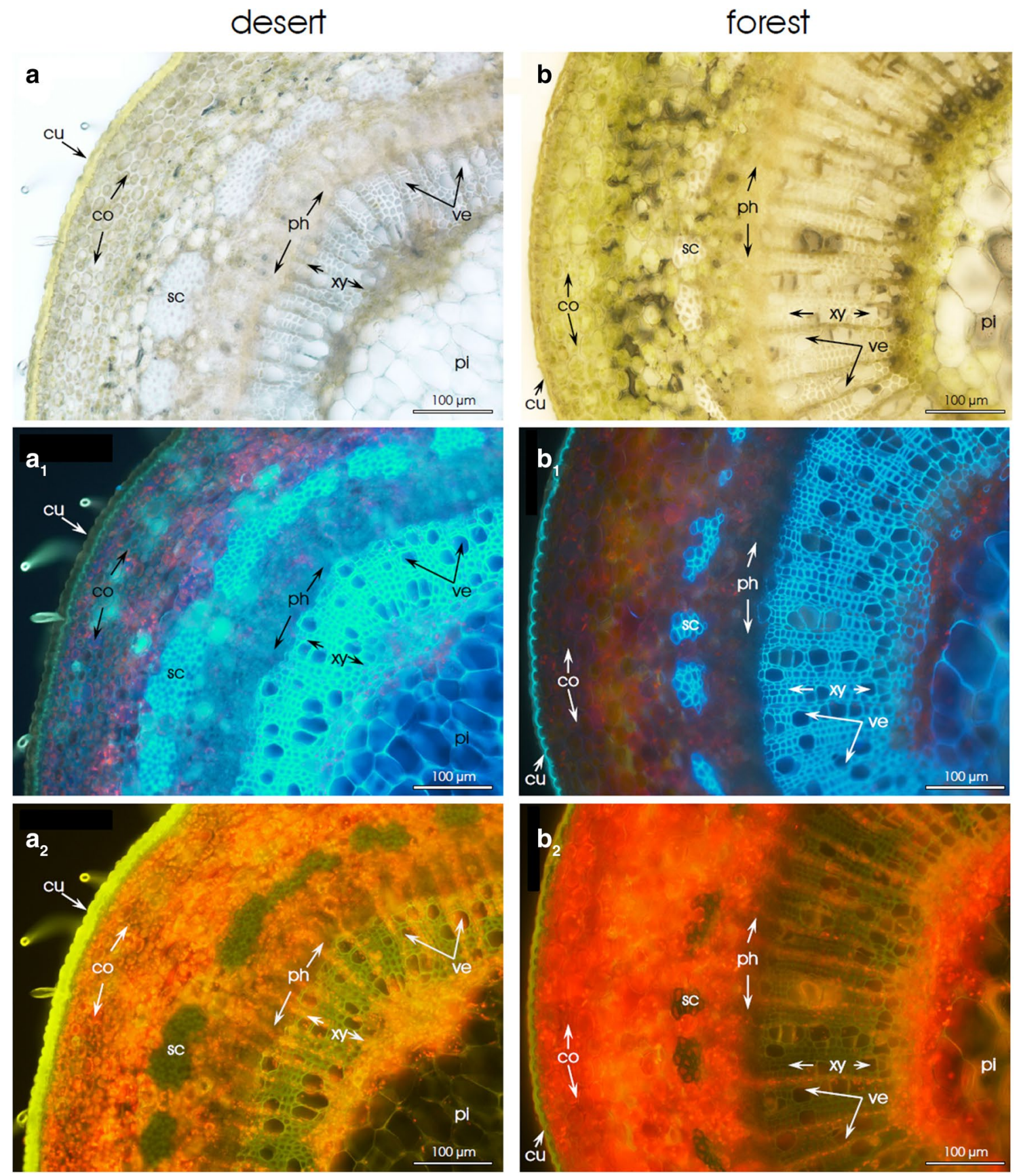

Fig. 3 Representative cross section of young stem (1 year old) of Salix repens subsp. arenaria (L.) Hiit. collected from Błędowska Desert "Pustynia Błędowska" (a) and surrounding forest (b) observed by light $(\mathbf{a}, \mathbf{b})$ and using epifluorescence microscopy $\left(\mathbf{a}_{\mathbf{1}}, \mathbf{a}_{\mathbf{2}}\right.$ and $\mathbf{b}_{\mathbf{1}}$,

and revealed no statistical dependence on the time of the measurement, nor on the plant location. However, some increasing tendency as observed during the course of a day could imply that the components responsible for the $\mathrm{DI}_{0} / \mathrm{RC}$ ratio got adapted to the new conditions very fast. Surprisingly, in the tested desert-growing plants, this parameter was not significantly higher in comparison to plants growing in $\mathbf{b}_{2}$ ). Red and blue colors correspond to autofluorescence of chlorophyll and cell walls, respectively. co-collenchyma; cu-cuticule; ph-phloem; pi-pith; sc—sclerenchyma; tr-trichome; $x y-x y l e m$; ve-vein

the surrounding forest. All the collected data could indicate that the photochemical apparatus in plants populating desert areas adapted slightly to strong light and drought by reducing the RC size while keeping their photochemical activity at a similar level.

Population assessment of soil microorganisms indicated that the rhizosphere of the forest soil substrate revealed 

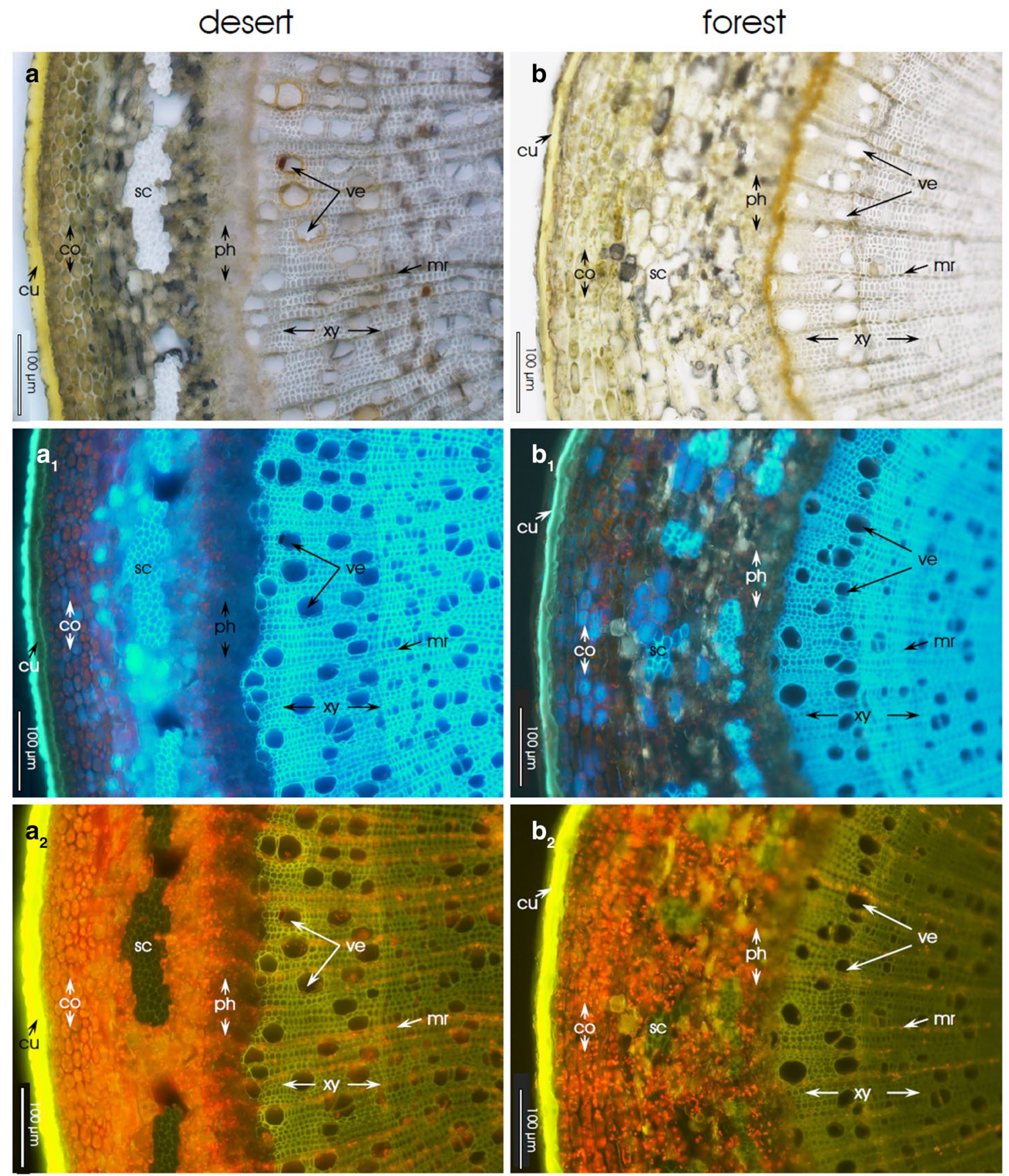

Fig. 4 Representative cross section of stem (2 year old) of Salix repens subsp. arenaria (L.) Hiit. collected from Błędowska Desert "Pustynia Błędowska" (a) and surrounding forest (b) observed by light (a, b) and using epifluorescence microscopy $\left(\mathbf{a}_{1}, \mathbf{a}_{2}\right.$ and $\left.\mathbf{b}_{1}, \mathbf{b}_{2}\right)$.

higher colonization frequency of both fungi and bacteria (Fig. 6) as compared to the desert stands (approximately two-to-threefold differences in microbial abundance). This tendency was observed both for the spring and summer seasons; however, in spring, the microbial population was generally much higher than in summer. The determined

Red and blue colors correspond to autofluorescence of chlorophyll and cell walls, respectively. co-collenchyma; cu-cuticule; mrmesophyll rays; ph-phloem; pi-pith; sc—sclerenchyma; tr-trichome; $x y$ - xylem; ve-vein

frequencies (expressed as CFUs per $\mathrm{g}$ d.w. of soil, given in pairs, as observed for the case of desert and forest, respectively) were as follows: (1) fungi (spring): $1.1 \times 10^{5}$ and $3.7 \times 10^{5}$; (summer): $1.0 \times 10^{4}$ and $7.1 \times 10^{4} ;(2)$ bacteria (spring): $2.8 \times 10^{7}$ and $4.4 \times 10^{8}$; (summer): $3.8 \times 10^{5}$ and $8.8 \times 10^{5}$ (cf. Fig. 6). As it is expected, the differences in 
Table 1 Carbon isotope ratios, $\delta^{13} \mathrm{C}$, measured in Salix arenaria leaves collected from plants growing in the Błędowska Desert and the nearby forest and derived carbon isotope discrimination and $p_{\mathrm{CO}_{2}}^{\mathrm{i}}$ (where $p_{\mathrm{CO}_{2}}^{\mathrm{a}}$ was taken as $400 \mathrm{~Pa} / \mathrm{MPa}$ ) according to Eqs. 1-4

\begin{tabular}{lll}
\hline Parameter & Desert & Forest \\
\hline$\delta^{13} \mathrm{C}(\% \circ)$ & -25.64 & -29.75 \\
$\Delta^{13} \mathrm{C}(\% o)$ & 18.1 & 22.4 \\
$p_{\mathrm{CO}_{2}}^{\mathrm{i}} / p_{\mathrm{CO}_{2}}^{\mathrm{a}}$ & 0.61 & 0.80 \\
$p_{\mathrm{CO}_{2}}^{\mathrm{i}}(\mathrm{Pa} / \mathrm{MPa})$ & 244 & 320 \\
\hline
\end{tabular}
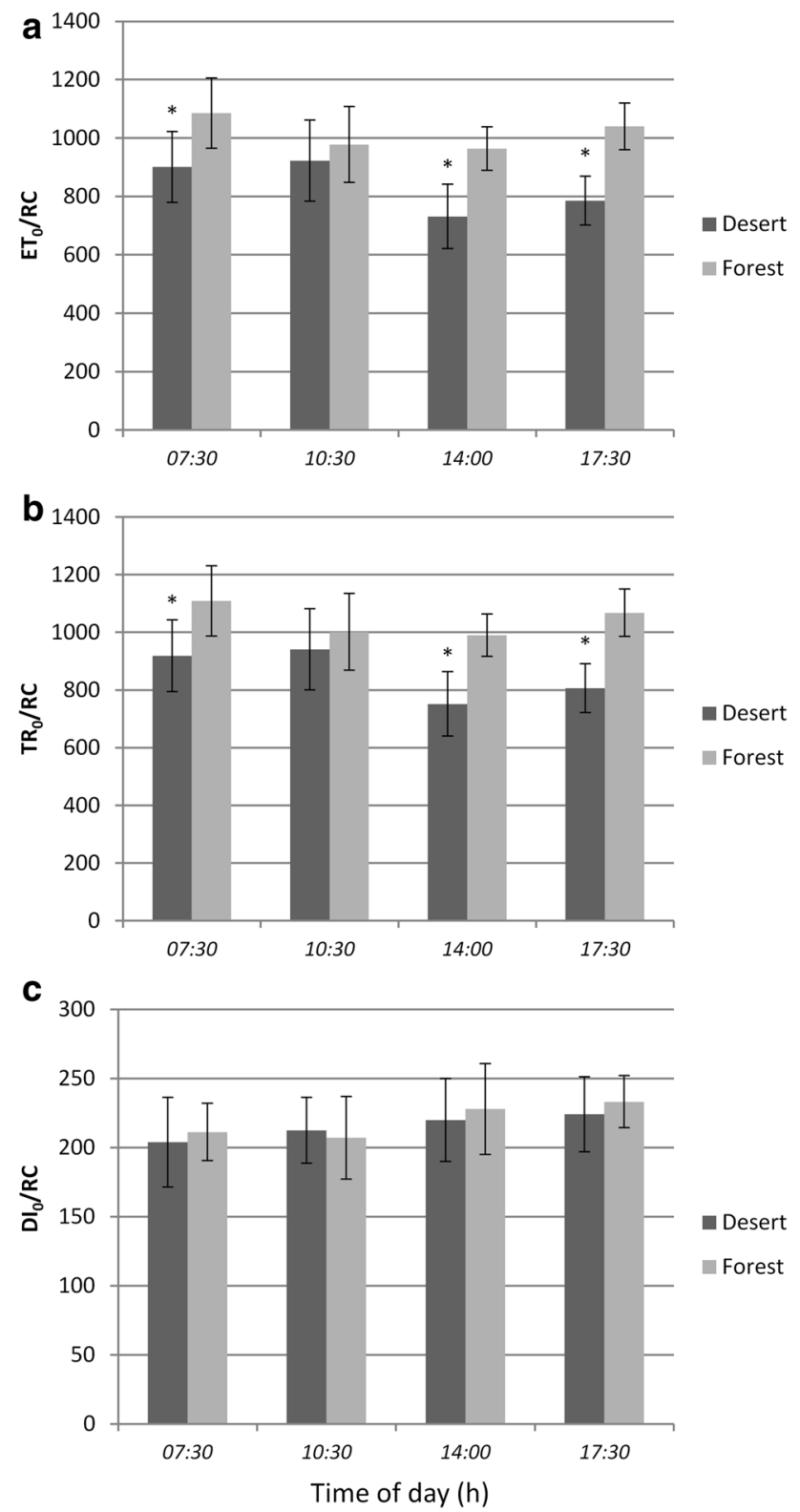

Fig. 5 Analyses of photochemical parameters of Salix arenaria growing in the desert and forest at different times of the day; a electron transport flux per reaction centers $\left(\mathrm{ET}_{0} / \mathrm{RC}\right) ; \mathbf{b}$ trapped energy flux per reaction centers $\left(\mathrm{TR}_{0} / \mathrm{RC}\right)$; $\mathbf{c}$ dissipated energy per reaction centers $\left(\mathrm{DI}_{0} / \mathrm{RC}\right)$; asterisks point to statistically significant differences at $p \leq 0.05$

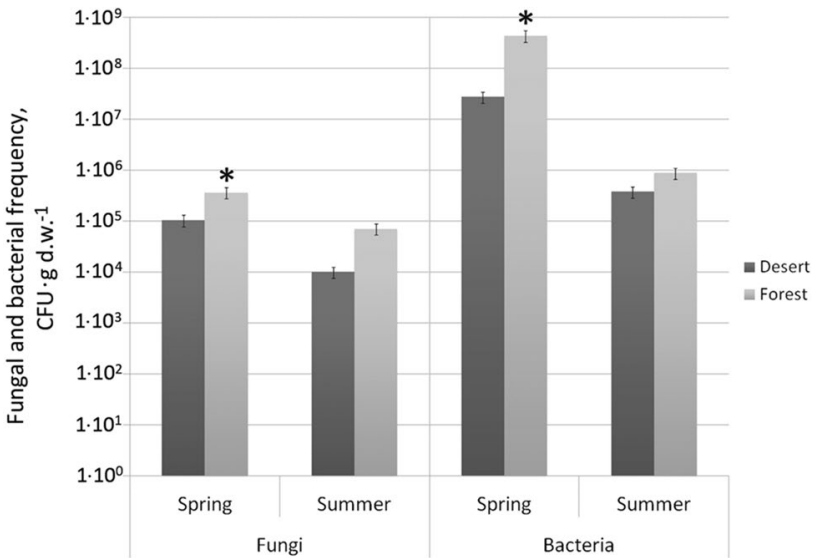

Fig. 6 Changes of fungal and bacterial population in the root zone of $S$. arenaria as dependent on the growth site (desert, forest) and season (spring, summer); asterisks point to statistically significant differences at $p \leq 0.05$

colonization rate suggest that the forest soil, richer in humic substances, provides better conditions for microbiota proliferation. Still, the observed microbial frequency of the sandy soil of the desert-growing plants should be regarded as high enough as not to hamper plant growth. Therefore, we can infer that the conditions in the willow root zones of the studied desert area were not inhibitory towards microorganisms. The higher microbial abundance observed during the spring season can be explained by more favorable water conditions, typically observed in May and June as compared to the summer months (data not shown).

Microscopic observations of arbuscular mycorrhiza (Fig. 7) show the well-formed symbiotic structures for $S$. arenaria growing both in desert and forest soils. These results were supported by the analyses of mycorrhizal frequency (unshown), and taken together, they prove similar fungal colonization rate of roots for the two cases studied.

\section{Concluding remarks}

Salix arenaria appears as a robust pioneer organism, capable of populating degraded areas such as desert-like habitats in Europe. The observed potential is similar to the one documented for other trees in tropical ecosystems. The plant can develop showing relatively small photochemical alterations and can reveal adaptive mechanisms enabling to adjust to unfavorable environment. It is expected to function as a nurse plant providing conditions that promote growth of other plants and stimulate proliferation of microorganisms. All the above findings indicate that $S$. arenaria is a good scrub candidate for introduction to degraded areas, capable of expansion under harsh environmental conditions. The highly productive $S$. arenaria vegetation may prove helpful 
Fig. 7 The arbuscular mycorrhiza in roots of creeping willow (Salix repens subsp. arenaria (L.) Hiit.) from the Błędowska Desert "Pustynia Błędowska" (a) and surrounding forest (b). hy-hyphae

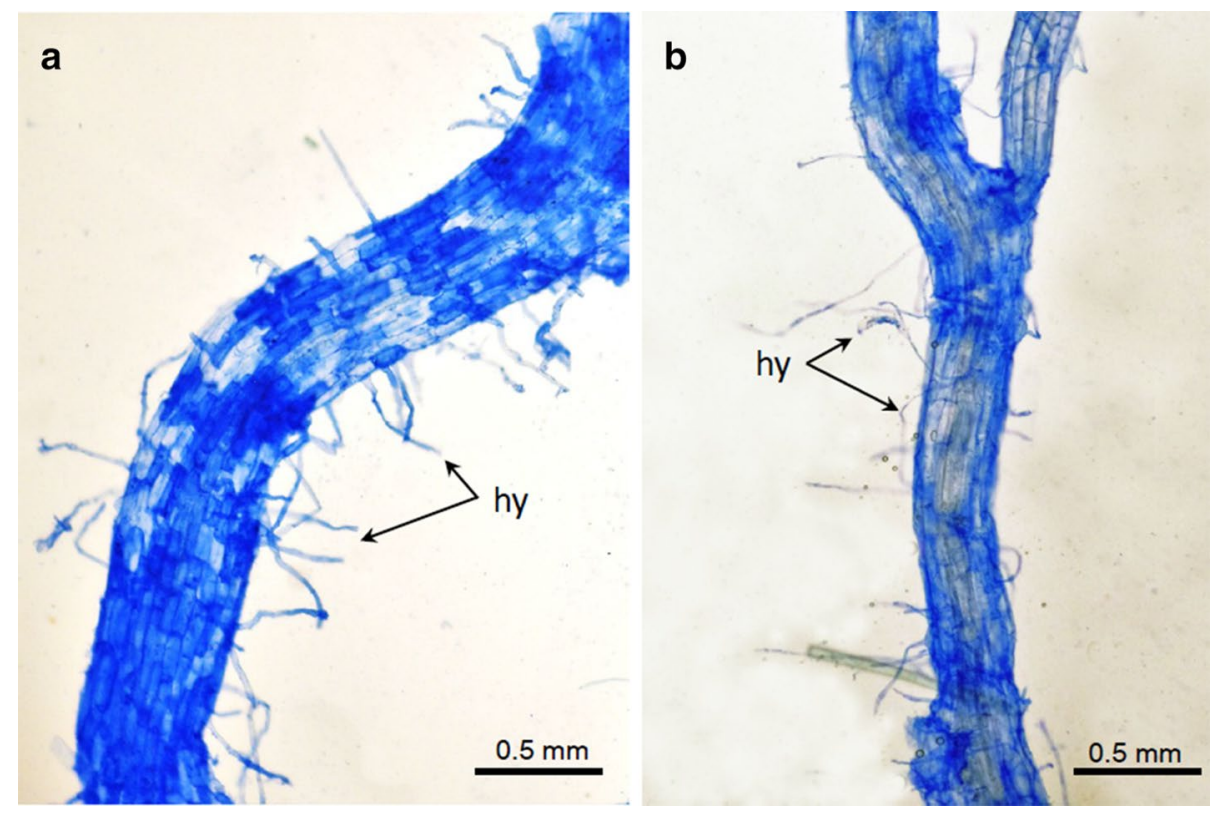

in slowing down the steppe formation and desertification as well as decreasing susceptibility to erosion of soils and deteriorated or anthropogenically affected areas.

Author contribution statement M Śliwa, P. Kaszycki, and Z. Miszalski contributed equally to the work, and together with U. Lüttge wrote the manuscript. All the authors participated in the field campaign and contributed to the measurements, data processing as well as elaboration of figures. Specific contributions: M. Śliwa evaluated mycorrhiza and together with A. Kaproń performed photochemical experiments, P. Supel carried out microbiological determinations, and A. Kornaś made microscopic plant anatomy observations.

Acknowledgements This research was financially supported by the Ministry of Science and Higher Education of the Republic of Poland. Additional funding is also greatly appreciated: the support to Z. Miszalski by the Alexander von Humboldt Foundation (AvH Stiftung) and to P. Supel by the German Academic Exchange Service (Deutscher Akademischer Austauschdienst, DAAD).

\section{Compliance with ethical standards}

Conflict of interest The authors declare that they have no conflict of interest.

Open Access This article is distributed under the terms of the Creative Commons Attribution 4.0 International License (http://creativeco mmons.org/licenses/by/4.0/), which permits unrestricted use, distribution, and reproduction in any medium, provided you give appropriate credit to the original author(s) and the source, provide a link to the Creative Commons license, and indicate if changes were made.

\section{References}

Allen MF, Swenson W, Querejeta JI, Egerton-Warburton LM, Treseder KK (2003) Ecology of mycorrhizae: a conceptual framework for complex interactions among plants and fungi. Annu Rev Phytopathol 41:271-303

Baker NR (2008) Chlorophyll fluorescence: a probe of photosynthesis in vivo. Annu Rev Plant Biol 59:89-113

Beerling DJ, Woodward FI (1993) Ecophysiological responses of plants to global environmental change since the last glacial maximum. New Phytol 125:641-648

Bonfante P, Genre A (2010) Mechanisms underlying beneficial plantfungus interactions in mycorrhizal symbiosis. Nat Commun 1:48

Cernusak LA, Ubierna N, Winter K, Holtum JA, Marshall JD, Farquhar GD (2013) Environmental and physiological determinants of carbon isotope discrimination in terrestrial plants. New Phytol 200:950-965

Coplen TB, Brand WA, Gehre M, Gröning M, Meijer HAJ, Toman B, Verkouteren RM (2006) New Guidelines for ${ }^{13} \mathrm{C}$ Measurements. Anal Chem 78:2439-2441

Dias ATC, Scarano FR (2007) Clusia as a nurse plant. In: Lüttge U (ed) Clusia - a woody neotropical genus of remarkable plasticity and diversity. Springer, Heidelberg, pp 55-71

Díaz-Zorita M, Perfect E, Grove JH (2002) Disruptive methods for assessing soil structure. Soil Tillage Res 64:3-22

Dickson S, Smith FA, Smith SE (2007) Structural differences in arbuscular mycorrhizal symbioses: more than 100 years after Gallaud, where next? Mycorrhiza 17:375-393

Ehleringer JR, Rundel PW (1989) Stable isotopes: history, units, and instrumentation. In: Rundel PW, Ehleringer JR, Nagy KA (eds) Stable isotopes in ecological research. Ecological studies. Springer, New York, pp 1-19

Facelli E, Smith SE, Smith FA (2009) Mycorrhizal symbiosis-overview and new insights into roles of arbuscular mycorrhizas in agro- and natural ecosystems. Australas Plant Pathol 38:338-344

Farquhar GD, O'Leary MH, Berry JA (1982) On the relationship between carbon isotope discrimination and inter-cellular carbondioxide concentration in leaves. Aust J Plant Physiol 9:121-137 
Farquhar GD, Ehleringer JR, Hubick KT (1989a) Carbon isotope discrimination and photosynthesis. Annu Rev Plant Physiol Plant Mol Biol 40:503-537

Farquhar GD, Hubick KT, Condon AG, Richards RA (1989b) Carbon isotope fractionation and plant water-use efficiency. In: Rundel PW, Ehleringer JR, Nagy KA (eds) Stable isotopes in ecological research. Ecological studies. Springer, New York, pp 21-40

Guehl J-M, Bonal D, Ferhi A, Barigah TS, Farquhar G, Granier A (2004) Community-level diversity of carbon-water relations in rainforest trees. In: Gourlet-Fleury S, Guehl J-M, Laroussinie O (eds) Ecology and management of a neotropical rainforest. Elsevier, Amsterdam, pp 75-94

Kalaji HM, Govindjee Bosa K, Kościelniak J, Żuk-Gołaszewska K (2011) Effects of salt stress on photosystem II efficiency and $\mathrm{CO}_{2}$ assimilation of two Syrian barley landraces. Environ Exp Bot 73:64-72

Kaszycki P, Supel P, Petryszak P (2014) Bacterial population dynamics in waste oily emulsions from the metal-processing industry. $\mathbf{J}$ Ecol Eng 15:14-22

Livingston NJ, Guy RD, Sun ZJ, Ethier GJ (1999) The effects of nitrogen stress on the stable carbon isotope composition, productivity and water use efficiency of white spruce (Picea glauca (Moench) Voss) seedlings. Plant Cell Environ 22:281-289

Lüttge U (2007) Physiological Ecology. In: Lüttge U (ed) Clusia-a woody neotropical genus of remarkable plasticity and diversity. Springer, Heidelberg, pp 187-234

Lüttge U, Garbin ML, Scarano FR (2012) Evo-devo-eco and ecological stem species: potential repair systems in the planetary crisis. Prog Bot 74:191-212

Medina E, Cram WJ, Lee HSJ, Lüttge U, Popp M, Smith JAC, Diaz M (1989) Ecophysiology of xerophytic and halophytic vegetation of a coastal alluvial plain in northern Venezuela. I. Site description and plant communities. New Phytol 111:233-243

Orłowska E, Zubek S, Jurkiewicz A, Szarek-Łukaszewska G, Turnau K (2002) Influence of restoration on arbuscular mycorrhiza of Biscutella laevigata L. (Brassicaceae) and Plantago lanceolata L. (Plantaginaceae) from calamine spoil mounds. Mycorrhiza 12:153-160

Park R, Epstein S (1961) Metabolic fractionation of $C^{13} \& C^{12}$ in plants. Plant Physiol 36:133-138

Pełka-Gościniak J, Rahmonov O, Szczypek T (2014) Stop 2.3. The Błędów Desert-past and future of the largest blow sands areas in Poland. In: Dulias R, Prokop P (eds) Land degradation and reclamation in the Silesian Upland and the Polish Carpathians. Faculty of Earth Sciences, University of Silesia, Department of Geoenvironmental Research, Institute of Geography and Spatial Organization, Polish Academy of Sciences, IGU Commission on Land Degradation and Desertification (COMLAND), Sosnowiec, Kraków, pp 76-80

Phillips JM, Hayman DS (1970) Improved procedures for clearing roots and staining parasitic and vesicular-arbuscular mycorrhizal fungi for rapid assessment of infection. Trans Br Mycol Soc 55:158-161

Rahmonov O, Oleś W (2010) Vegetation succession over an area of a medieval ecological disaster. The case of the Błędów Desert, Poland. Erdkunde 64:241-255
Rahmonov O, Snytko VA, Szczypek T (2009) Phytogenic hillocks as an effect of indirect human activity. Z Geomorphol 53:359-370

Raport o oddziaływaniu na środowisko przedsięwzięcia polegającego na eksploatacji rud cynku i ołowiu ze złoża „KLUCZE I” położonego na terenie gminy Klucze, woj. Małopolskie, Inwestor: ZGH „BOLESŁAW” SA. w Bukownie, opracowanie: „ATem”, Anna Twardowska-Nowak, Siemianowice Śląskie, 2007 (Report on the environmental impact... of exploitation of zinc and lead ores at the „KLUCZE I” deposit..., 2007, in Polish)

Rillig MC, Mummey DL (2006) Mycorrhizas and soil structure. New Phytol 171:41-56

Scheidegger Y, Saurer M, Bahn M, Siegwolf R (2000) Linking stable oxygen and carbon isotopes with stomatal conductance and photosynthetic capacity: a conceptual model. Oecologia 125:350-357

Seibt U, Rajabi A, Griffiths H, Berry JA (2008) Carbon isotopes and water use efficiency: sense and sensitivity. Oecologia 155:441-454

Smith S, Read D (2008) Mycorrhizal symbiosis, 3rd edn. Academic Press, Amsterdam

Smith SE, Facelli E, Pope S, Smith FA (2010) Plant performance in stressful environments: interpreting new and established knowledge of the roles of arbuscular mycorrhizas. Plant Soil 326:3-20

Szostak M, Wężyk P, Hawryło P, Puchała M (2016) Monitoring the secondary forest succession and land cover/use changes of the Błędów Desert (Poland) using geospatial analyses. Quaest Geogr 35:5-13

Trouvelot A, Kough JL, Gianinazzi-Pearson V (1986) Mesure du taux de mycorhization VA d'un système radiculaire. Recherche de méthodes d'estimation ayant une signification fonctionnelle. In: Gianinazzi-Pearson V, Gianinazzi S (eds) Physiological and genetical aspects of mycorrhizae. INRA Press, Paris, pp 217-221

Van Der Heijden EW, Kuyper TW (2001) Laboratory experiments imply the conditionality of mycorrhizal benefits for Salix repens: role of $\mathrm{pH}$ and nitrogen to phosphorus ratios. Plant Soil 228:275-290

Wonkka CL, Lafon CW, Hutton CM, Joslin AJ (2013) A CSR classification of tree life history strategies and implications for ice storm damage. Oikos 122:209-222

Zander M, Graf W (2010) Salix repens ssp. arenaria (L.) hiltonen 'böschungsprinzessin'-a new creeping willow cultivar with a good drought stress tolerance. Acta Hort 885:429-436

Zarządzenie Regionalnego Dyrektora Ochrony Środowiska w Krakowie i Regionalnego Dyrektora Ochrony Środowiska w Katowicach z dnia 31 lipca 2014 r. w sprawie ustanowienia planu zadań ochronnych dla obszaru Natura 2000 Pustynia Błędowska PLH120014, Dz. Urz. Województwa Małopolskiego z 04.08.2014 r. Poz. 4258, Dz. Urz. Województwa Śląskiego z 04.08.2014 r. Poz. 4210 (Ordinance of the Regional Director for Environmental Protection, Kraków, Katowice, 2014, in Polish)

Publisher's Note Springer Nature remains neutral with regard to jurisdictional claims in published maps and institutional affiliations. 